\title{
Electrochemical Reduction of Bromate by a Pd Modified Carbon Fiber Electrode: Kinetics and Mechanism
}

\author{
Ran Mao ${ }^{\mathrm{a}, \mathrm{b}}$, Xu Zhao ${ }^{\mathrm{a}, *}$, Jiuhui $\mathrm{Qu}^{\mathrm{a}}$ \\ a Key Laboratory of Drinking Water Science and Technology, Research Center for Eco-Environmental Sciences, Chinese Academy of Sciences, Beijing, \\ 100085, P.R. China \\ ${ }^{\mathrm{b}}$ University of Chinese Academy of Sciences, Beijing, 100049, P.R. China
}

\section{A R T I C L E I N F O}

\section{Article history:}

Received 30 December 2013

Received in revised form 23 March 2014

Accepted 29 March 2014

Available online 8 April 2014

\section{Keywords:}

Electro-reduction

bromate removal

$\mathrm{Pd} / \mathrm{C}$ electrode

\begin{abstract}
A B S T R A C T
The electroreduction of bromate $\left(\mathrm{BrO}_{3}{ }^{-}\right)$was investigated at a Pd modified carbon fiber (Pd/C) electrode prepared from $\mathrm{PdCl}_{2}$ via electrodeposition method. Pd particles distributed on the carbon fiber substrate uniformly. Under various cathode potentials, electroreduction removal of $\mathrm{BrO}_{3}{ }^{-}$at pure carbon fiber electrode and the $\mathrm{Pd} / \mathrm{C}$ electrode were firstly compared. It was observed that nearly no $\mathrm{BrO}_{3}{ }^{-}$removal was observed within the bias potential of $-2.0 \mathrm{~V}$ at the carbon fiber electrode. At the $\mathrm{Pd} / \mathrm{C}$ electrode, the removal efficiency of $\mathrm{BrO}_{3}{ }^{-}$was sharply increased from $24.0 \%$ to $58.4 \%$ at the cathode potential of -1.0 to $-1.5 \mathrm{~V}$, which was further increased to be $87.2 \%$ at $-2.0 \mathrm{~V}$. The electrochemical reduction of $\mathrm{BrO}_{3}-$ was strongly $\mathrm{pH}$-dependent at $-0.5 \mathrm{~V}$ and the reduction rate could be enhanced at low $\mathrm{pH}$. While at the potential of $-2.0 \mathrm{~V}$, a slight $\mathrm{pH}$ effect was observed. $\mathrm{BrO}_{3}-$ electroreduction follows pseudo first-order kinetics; the rate constant $\mathrm{k}$ was firstly increased from 0.016 to $0.031 \mathrm{~min}^{-1}$ with the increase of the Pd loading amount from 0.31 to $0.73 \mathrm{mg} / \mathrm{cm}^{2}$, and then was decreased to $0.018 \mathrm{~min}^{-1}$ at a higher Pd loading amount of $1.05 \mathrm{mg} / \mathrm{cm}^{2}$. The $\mathrm{Pd}(0)$ nanoparticles played a significant role in forming atomic $\mathrm{H}^{*}$ to realize indirect $\mathrm{BrO}_{3}{ }^{-}$reduction. The electrochemical reduction of $\mathrm{BrO}_{3}{ }^{-}$produces accumulated intermediates of $\mathrm{HOBr}$ and $\mathrm{OBr}^{-}$, which were subsequently reduced to $\mathrm{Br}^{-}$with the time evolution.
\end{abstract}

(c) 2014 Elsevier Ltd. All rights reserved.

\section{Introduction}

Bromate $\left(\mathrm{BrO}_{3}{ }^{-}\right)$is an oxyhalide disinfection byproduct frequently detected in drinking water from ozonation or chlorination of bromide $\left(\mathrm{Br}^{-}\right)$-containing source waters [1,2]. $\mathrm{BrO}_{3}{ }^{-}$has been recognized as a potential carcinogen to humans, thereby the World Health Organization (WHO) has strictly regulated $\mathrm{BrO}_{3}{ }^{-}$level in drinking water [3]. Thus, it is highly desirable to develop effective treatment methods to remove $\mathrm{BrO}_{3}{ }^{-}$pollutants.

Conventionally, $\mathrm{BrO}_{3}{ }^{-}$can be removed by various technologies including filtration, photocatalysis, arc discharge, chemical reduction, activated carbon techniques, and biological remediation [4-7]. Among these technologies, the iron-based chemical reduction and biological activated carbon (BAC) treatment has been well discussed in the research papers [8-11]. Although these two approaches can efficiently reduce $\mathrm{BrO}_{3}{ }^{-}$to $\mathrm{Br}^{-}$, their feasibility in water treatment was limited because of the extended reaction time for BAC treatment and requirement for post-treatment to remove

\footnotetext{
* Corresponding author. Tel.: +86 10 62849160; fax: +86 1062849160 .

E-mail address: zhaoxu@rcees.ac.cn (X. Zhao).
}

$\mathrm{Fe}^{2+}$ or residual biomass $[12,13]$. In recent years, there has been an increased interest in environmental applications of electrochemical processes, which are chemical-free, electricity driven, highly efficient and selective, and easy to realize automatic operation [14-18]. The compact reactor size, minimal formation of byproducts and low maintenance requirements of the electrochemical process make it highly attractive as point of use drinking water treatment [19]. Electrochemical technologies have been proven effective for eliminating $\mathrm{BrO}_{3}{ }^{-}$from water. For example, Kishimoto and Matsuda reported a novel electrochemical method to reduce $\mathrm{BrO}_{3}{ }^{-}$to $\mathrm{Br}^{-}$using an activated carbon felt electrode [20]. $\mathrm{BrO}_{3}{ }^{-}$ contamination can be removed within a few minutes. But, this process required acidic conditions. Zhao et al. studied the effectiveness of $\mathrm{BrO}_{3}{ }^{-}$removal by electrochemical reduction at a boron-doped diamond electrode, which can remove nearly $90 \%$ of $\mathrm{BrO}_{3}{ }^{-}$with the applied bias potential of $-1.0 \mathrm{~V}$ within $2 \mathrm{~h}$ [21]. The electrochemical process can reduce $\mathrm{BrO}_{3}{ }^{-}$to $\mathrm{Br}^{-}$with enhanced reaction rates, and no additional treatment processes are required.

It is recognized that the reduction of contaminants at cathode surfaces may occur through both direct and indirect mechanisms [22]. Direct reduction occurs by electron tunneling, and indirect reduction of contaminants occurs via reaction with atomic 
hydrogen adsorbed on the cathode [23]. Nevertheless, the direct reduction of contaminants at the cathode required suitable electrocatalytic electrode materials, which usually worked at high overpotentials to obtain vigorous reduction conditions [24]. Apart from this, $\mathrm{H}_{2}$ generated at the cathode by water electrolysis during the electrochemical process was considered to reduce the efficiency and consumed the energy [25]. Recent studies have shown that $\mathrm{H}_{2}$ produced at the cathode can be delivered for palladium (Pd)-catalytic hydrodechlorination of contaminants, thus providing an alternative to reduce the dependence on costly electrode materials [26,27]. For example, Bonin et al. exhibited that Pd-modified cathodes had high dechlorination efficiencies for chlorinated organics, as Pd can activate $\mathrm{H}_{2}$ as well as catalyze the electrochemical reduction of $\mathrm{H}^{+}$or $\mathrm{H}_{2} \mathrm{O}$ to produce continuously adsorbed nascent $H^{*}[28,29]$. This indirect electroreduction process known as electrocatalytic hydrogenolysis, in which reductive atomic hydrogen is generated at the electrode surface, is indeed a very useful tool for the reductive transformation of contaminants. Therefore, the Pd-modified cathodes are expected to be effective in $\mathrm{BrO}_{3}{ }^{-}$reduction. However, for $\mathrm{BrO}_{3}{ }^{-}$reduction, the electrochemical activity and the electrocatalytic reduction process with a Pd-modified cathode have not been investigated.

The objective of this study was to explore the reaction mechanism of the electrocatalytic reduction of $\mathrm{BrO}_{3}{ }^{-}$on the $\mathrm{Pd} / \mathrm{C}$ electrode. $\mathrm{BrO}_{3}-$ reduction at different cathode potentials, $\mathrm{pH}$ values, supporting electrolyte concentrations and Pd loadings was investigated. The direct and indirect reduction processes were specifically elucidated.

\section{Experimental}

\subsection{Chemicals}

The carbon fiber was purchased from Beijing LN Power Source Company (Toray 120). Proton exchange membrane used in the experiments was Nafion-117 (Du Pont). Other chemicals including sodium bromate, sodium bromide, palladium chloride and ammonium chloride were obtained from Sinopharm Chemical Reagent Co. Ltd. All chemicals used in this study were analytical grade. Highpurity water (specific conductivity of $18.2 \mathrm{M} \Omega \mathrm{cm}^{-1}$ ) obtained from a Millipore Milli-Q system was used in all the experiments.

\subsection{Electrode preparation}

The Pd/C electrode was prepared via our previously reported electrodeposition method [30]. Briefly, the carbon fiber was first immersed in a $0.1 \%(\mathrm{w} / \mathrm{w})$ Triton X-100 solution for $24 \mathrm{~h}$ and then in de-ionized water for $2 \mathrm{~h}$ for the purpose of lowering the hydrophobicity and the extent of metal agglomeration [31,32]. The electrodeposition of $\operatorname{Pd}(0)$ was carried out by dipping the cleaned carbon fiber in dichlorodiammine palladium $\left[\mathrm{Pd}\left(\mathrm{NH}_{3}\right)_{2} \mathrm{Cl}_{2}\right]$ complex (plating solution, $\mathrm{pH}=1$ ), composed of $1 \mathrm{mM}$ palladium chloride $\left(\mathrm{PdCl}_{2}\right)$ and $10 \mathrm{mM}$ ammonium chloride solution [33]. The desired amount of Pd particles were electrodeposited onto the carbon fiber with a current density of $2 \mathrm{~mA} / \mathrm{cm}^{2}$ for $30 \mathrm{~min}$. The as prepared Pd/C electrode was subsequently reduced at $200^{\circ} \mathrm{C}$ for $2 \mathrm{~h}$ with rates of $100 \mathrm{~mL} / \mathrm{min} \mathrm{H}_{2}$ to immobilize the catalysts.

\subsection{Apparatus}

The electrocatalytic reduction of $\mathrm{BrO}_{3}{ }^{-}$in aqueous solution was conducted in an electrochemical reactor separated into two cells by the proton exchange membrane (Figure S1). The cathode and the anode compartments were filled with $50 \mathrm{~mL}$ aqueous solution of $\mathrm{BrO}_{3}{ }^{-}$with $\mathrm{Na}_{2} \mathrm{SO}_{4}$ (supporting electrolyte) and $\mathrm{Na}_{2} \mathrm{SO}_{4}$, respectively. The reactor was connected with an EG\&G model $263 \mathrm{~A}$ workstation (Princeton Applied Research, USA). The prepared Pd/C electrode was used as the cathode with a geometric surface area of $7.5 \mathrm{~cm}^{2}(2.5 \mathrm{~cm} \times 3 \mathrm{~cm})$, and the anode was a platinum wire with $72 \mathrm{~mm}$ in length and $1.5 \mathrm{~mm}$ in diameter. A saturated calomel electrode (SCE) was positioned near the cathode as the reference electrode. To ensure the homogeneity of the catholyte, the system was magnetically stirred at a rate of $700 \mathrm{rpm}$. The potentiostatic electrolysis was applied in the experiments and $\mathrm{Na}_{2} \mathrm{SO}_{4}$ was employed as the background electrolyte. All electrolysis experiments were completed at $5 \mathrm{mM} \mathrm{Na}_{2} \mathrm{SO}_{4}$ unless otherwise noted. During the electrolysis, samples were periodically withdrawn from the cathode cell for analysis. The solution $\mathrm{pH}$ was adjusted with diluted $\mathrm{H}_{2} \mathrm{SO}_{4}$ and $\mathrm{NaOH}$ solution (guaranteed grade).

\subsection{Analysis}

The concentrations of $\mathrm{BrO}_{3}{ }^{-}$and $\mathrm{Br}^{-}$were measured with an ion chromatograph (IC) (Dionex 2000) using an IonPac AS-19 anionexchange analytical column and an IonPac AG19 guard column. Mobile phase eluent for the IC was $\mathrm{KOH}$ solution, and the flow rate was $1.0 \mathrm{~mL} / \mathrm{min}$. The chromatogram of $\mathrm{BrO}_{3}{ }^{-}$and $\mathrm{Br}^{-}$was obtained under gradient elution conditions (0.0-18.0 min: $10.0 \mathrm{mM}$ $\mathrm{KOH}$; 18.1-26.0 min: 35.0 mM KOH; 26.1-31.0 min: $10.0 \mathrm{mM} \mathrm{KOH).}$

Scanning electron microscopy (SEM) and energy-dispersive Xray spectroscopy (EDX) were carried out in a JSM 6301 instrument X-ray photoelectron spectroscopy (XPS) analysis was performed with a Kratos AXIS Ultra X-ray photoelectron spectrometer. X-ray powder diffraction (XRD) patterns of samples were obtained with an X'Pert PRO Powder diffractometer machine (PANalytical Co.), by using Ni-filtered $\mathrm{Cu} \mathrm{K}_{\alpha}$ irradiation from $5^{\circ}$ to $90^{\circ}$ (in $2 \theta$ ).

\section{Results and Discussion}

\subsection{Characterization of the $P d / C$ electrode}

The $\mathrm{Pd} / \mathrm{C}$ electrodes with various Pd loading amounts were firstly characterized by SEM and EDX analysis. As presented in Fig. 1 (a), the bare carbon fiber is comprised of hundreds of carbon fiber. The ample inner space of carbon fiber can provide optimal channels for targeted $\mathrm{BrO}_{3}{ }^{-}$anions to transfer to the catalytic active sites. Abundant sphere-like electrodeposited Pd particles disperse evenly on the carbon fiber as can be seen from images with higher magnification (Fig. 1 (b), (c),(d)). The size of the Pd particles is around $40 \mathrm{~nm}$ in diameter. The effect of Pd loading amount on the catalytic behavior of the $\mathrm{Pd} / \mathrm{C}$ electrode will be addressed subsequently. In fact, the Pd loading amount of $1.05 \mathrm{mg} / \mathrm{cm}^{2} \mathrm{Pd} / \mathrm{C}$ electrode is approximately 3.4-fold and 1.4-fold higher than that of $0.31 \mathrm{mg} / \mathrm{cm}^{2}$ and $0.73 \mathrm{mg} / \mathrm{cm}^{2} \mathrm{Pd} / \mathrm{C}$ electrode, respectively. Data in Figure S2 also indicates the same feature, namely $0.72 \% \mathrm{Pd}$ atoms percent is also nearly 3.4 -fold and 1.6 -fold as large as $0.21 \%$ and $0.44 \%$ Pd atoms percent, respectively. Therefore, the EDX results confirm the existence of increased Pd loading amounts on the Pd/C electrodes.

XRD spectra of the carbon fiber electrode and the prepared $\mathrm{Pd} / \mathrm{C}$ electrode were given in Figure S3. The peak at $26.5^{\circ}$ is attributed to the highly structured (graphitic) carbon, and the diffraction peaks occurring at $40.2^{\circ}$ and $46.8^{\circ}$ are assigned to typical Pd metal with face centered cubic crystallographic structure [34,35]. The peaks at $68.3^{\circ}$ and $82.3^{\circ}$ are respectively for (220) and (311) planes, indicating the polycrystalline state of Pd particles electrodeposited onto the carbon fiber.

\subsection{Effect of cathode potential}

Electroreduction of $\mathrm{BrO}_{3}{ }^{-}$on the $\mathrm{Pd} / \mathrm{C}$ electrode at different cathode potentials is investigated and the results are presented in 


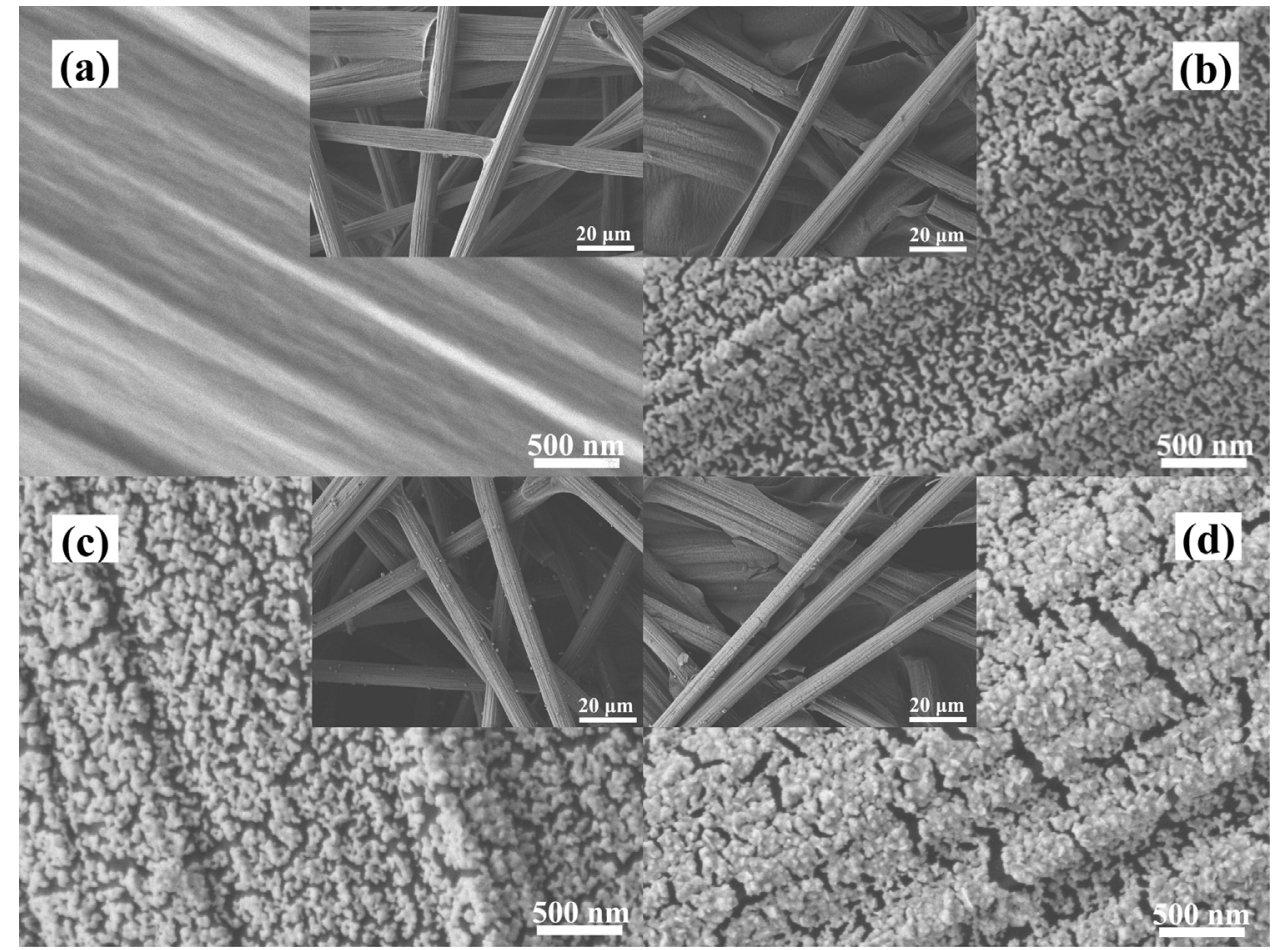

Fig. 1. SEM images of the Pd/C electrodes with various Pd loading amounts. (a) $0 \mathrm{mg} / \mathrm{cm}^{2} ;$ (b) $0.31 \mathrm{mg} / \mathrm{cm}^{2} ;(\mathrm{c}) 0.73 \mathrm{mg} / \mathrm{cm}^{2} ; \mathrm{and}(\mathrm{d}) 1.05 \mathrm{mg} / \mathrm{cm}^{2}$.

Fig. 2 (a). Nearly no loss of $\mathrm{BrO}_{3}{ }^{-}$is observed at the applied potential of $-0.3 \mathrm{~V}$ (vs. SCE) and $-0.5 \mathrm{~V}$ within $60 \mathrm{~min} .24 .0 \%$ of the $\mathrm{BrO}_{3}{ }^{-}$ is removed at $-1.0 \mathrm{~V} . \mathrm{BrO}_{3}{ }^{-}$removal is largely increased to be $87.2 \%$ at $-2.0 \mathrm{~V}$ under the same otherwise conditions. Further decrease of the applied bias potential to $-2.5 \mathrm{~V}$ does not increase the removal efficiency.

The pseudo first-order reaction kinetics is used to fit the $\mathrm{BrO}_{3}$ removal with the reaction time. The model is given by the equation of (1)

$\mathrm{C}_{\mathrm{t}}=\mathrm{C}_{0} \exp (-\mathrm{kt})$

where $\mathrm{t}$ is the reaction time $(\mathrm{min}), \mathrm{k}$ is the rate constant $\left(\mathrm{min}^{-1}\right)$, and $\mathrm{C}_{0}$ and $\mathrm{C}_{\mathrm{t}}$ are the $\mathrm{BrO}_{3}{ }^{-}$concentrations $(\mu \mathrm{M})$ at times of $\mathrm{t}=0$ and $\mathrm{t}=\mathrm{t}$, respectively. The kinetic analysis of the data in Fig. 2 (a) gives an average correlation coefficient for the $\ln \left[\mathrm{BrO}_{3}{ }^{-}\right]$versus $t$ plot in the linear region of 0.993 , suggesting the suitability of the pseudo first-order reaction kinetics used to fit $\mathrm{BrO}_{3}{ }^{-}$removal. As shown in Fig. 2 (b), the value of $k$ remains low until the applied bias potential is $-1.0 \mathrm{~V}$, where it begins to rise sharply with the potential decreasing to $-2.0 \mathrm{~V}$, and then reaches a plateau of $0.031 \mathrm{~min}^{-1}$ when the cathode is operated at more reducing values. A similar trend was reported by Li et al. in the reduction dehalogenation of chloroacetic acids [36]. It was exhibited that the electrocatalytic dehalogenation happened at potentials lower than $-1.0 \mathrm{~V}$ where molecular hydrogen would evolve. $\mathrm{Pd}(0)$ played important roles in the chemisorption and decomposition of hydrogen into atomic $\mathrm{H}^{*}$, a highly activated intermediate hydrogen radical [37]. Atomic $\mathrm{H}^{*}$ adsorbed on the surface of the electrode at low cathode potentials is beneficial for the electroreduction of $\mathrm{BrO}_{3}{ }^{-}$. Moreover, it is reasonable to hypothesize that the relatively low removal efficiency at potentials higher than $-1.0 \mathrm{~V}$ is due to absence of atomic $\mathrm{H}^{*}$ so that $\mathrm{BrO}_{3}{ }^{-}$can only be removed by the direct reduction at the $\mathrm{Pd} / \mathrm{C}$ electrode.

\subsection{Effect of solution $\mathrm{pH}$}

A comparison of $\mathrm{BrO}_{3}{ }^{-}$reduction at -0.5 and $-2.0 \mathrm{~V}$ with various $\mathrm{pH}$ values was performed in order to explore the role of $\mathrm{H}+$ in the electroreduction of $\mathrm{BrO}_{3}{ }^{-}$. As shown in Fig. 3 (a), the relative moles vs time plot at $-0.5 \mathrm{~V}$ shows that the $\mathrm{BrO}_{3}{ }^{-}$removal rate strongly depends on the solution $\mathrm{pH}$. The electroreduction rate of $\mathrm{BrO}_{3}{ }^{-}$is decreased from 0.0203 to $0.0014 \mathrm{~min}^{-1}$ upon increasing $\mathrm{pH}$ from 2.73 to 9.39. By contrast, in the electrochemical reduction of $\mathrm{BrO}_{3}{ }^{-}$ at $-2.0 \mathrm{~V}$, a negligible influence of solution pH is observed (Fig. 3 (b)). The electroreduction rate of $\mathrm{BrO}_{3}{ }^{-}$remains around $0.031 \mathrm{~min}^{-1}$ when $\mathrm{pH}$ is increased from 2.09 to 9.88 , reflecting a stable electrocatalytic activity of the $\mathrm{Pd} / \mathrm{C}$ electrode with a wide $\mathrm{pH}$ range. The different electroreduction behavior with various $\mathrm{pH}$ ranges indicated that the electroreduction of $\mathrm{BrO}_{3}{ }^{-}$proceed with a different reduction process at $-2.0 \mathrm{~V}$.

The similar strong dependence of $\mathrm{BrO}_{3}{ }^{-}$reduction on $\mathrm{pH}$ value was observed by Kishimoto et al. and Chen et al. [20,38]. They pointed out that low solution $\mathrm{pH}$ can accelerate the $\mathrm{BrO}_{3}{ }^{-}$removal. Reactions occurring at the electrode are heterogeneous and aqueous electrons coupled with $\mathrm{H}^{+}$are considered to take part in the direct reduction of $\mathrm{BrO}_{3}{ }^{-}$on the cathode surface. Therefore, $\mathrm{H}^{+}$concentration is important to the chemical equilibrium of the overall reaction. Nevertheless, when the applied bias potential is decreased to $-2.0 \mathrm{~V}$, the notably increased atomic $\mathrm{H}^{*}$ gathered on the Pd particles may efficiently reduce $\mathrm{BrO}_{3}{ }^{-}$to $\mathrm{Br}^{-}$[29]. On the basis of the above analysis, the electrochemical reduction of $\mathrm{BrO}_{3}{ }^{-}$proceeds with indirect mechanism at low cathode potentials, and $\mathrm{H}^{+}$concentration seems insignificant due to the high catalytic ability of the $\mathrm{Pd}$ particles for the indirect $\mathrm{BrO}_{3}{ }^{-}$reduction. This electrochemical reduction behavior of $\mathrm{BrO}_{3}$ - is in agreement with reports in the literature in which slight $\mathrm{pH}$ effects were observed for TCE reduction in the Pd modified electrode reactor [22]. They reported that although the higher $\mathrm{pH}$ values contributed to decreased cathodic production of hydrogen in both the untreated and Pd modified 
(a)
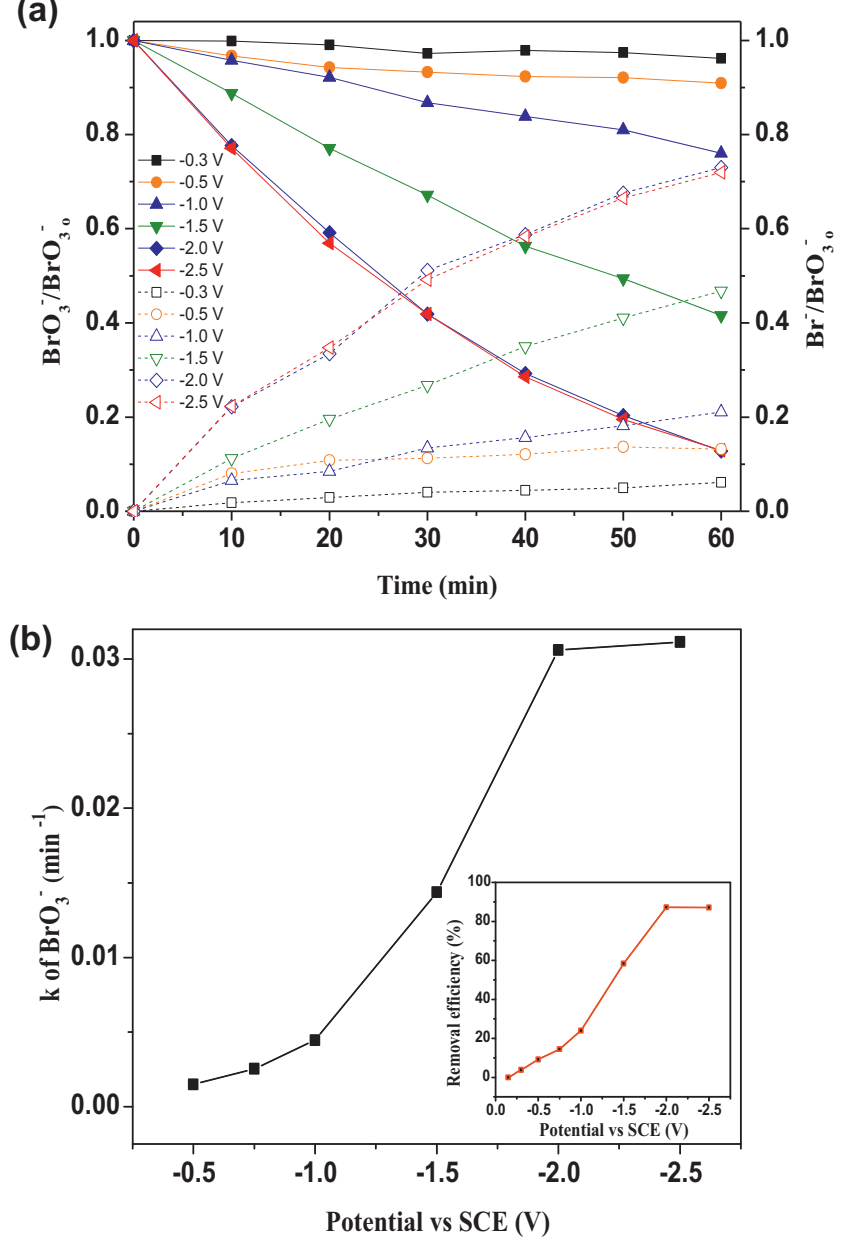

Fig. 2. (a) Electrocatalytic reduction of $\mathrm{BrO}_{3}{ }^{-}$and $\mathrm{Br}^{-}$generation at different applied potentials (filled symbols denote normalized $\mathrm{BrO}_{3}{ }^{-}$concentration and open symbols denote normalized $\mathrm{BrO}^{-}$concentration), (b) effect of applied bias potential on the $\mathrm{BrO}_{3}{ }^{-}$reduction kinetics at the $\mathrm{Pd} / \mathrm{C}$ electrode $\left(5 \mathrm{mM} \mathrm{Na}_{2} \mathrm{SO}_{4} ; 0.66 \mu \mathrm{M}\right.$ initial $\mathrm{BrO}_{3}$ concentration; Pd loading amount: $0.73 \mathrm{mg} / \mathrm{cm}^{2}$ ). The inset in (b) illustrates the effect of applied bias potential on the $\mathrm{BrO}_{3}{ }^{-}$removal efficiency.

iron reactors, the palladium could concentrate the available hydrogen, leading to smaller $\mathrm{pH}$ effects than that in the iron reactor. Their observation also supported the conclusion that atomic $\mathrm{H}^{*}$ was involved in the $\mathrm{BrO}_{3}{ }^{-}$reduction by the Pd modified electrode.

\subsection{Effect of $\mathrm{Na}_{2} \mathrm{SO}_{4}$ concentration}

As shown in Fig. 4, within $120 \mathrm{~min}$, the $\mathrm{BrO}_{3}{ }^{-}$concentration decreases by $25.5 \%$ and $57.1 \%$ with $\mathrm{Na}_{2} \mathrm{SO}_{4}$ concentration of $0.1 \mathrm{mM}$ and $1.0 \mathrm{mM}$ at the constant potential of $-2.0 \mathrm{~V}$, respectively. When the $\mathrm{Na}_{2} \mathrm{SO}_{4}$ concentration is increased to $10 \mathrm{mM}$, a sharp decline in $\mathrm{BrO}_{3}{ }^{-}$concentration within $30 \mathrm{~min}$ is observed and the residual concentration is below detection limits of the analytic method used in this study $(0.5 \mu \mathrm{g} / \mathrm{L})$. Actually, there is a rise in electrolytic current upon increasing $\mathrm{Na}_{2} \mathrm{SO}_{4}$ concentration, and thus more atomic $\mathrm{H}^{*}$ cover the surface of the cathode, thereby the adsorbed $\mathrm{BrO}_{3}{ }^{-}$are more likely to acquire atomic $\mathrm{H}^{*}$. The results are consistent with the hypothesis that indirect reduction was predominant under the tested conditions.

\subsection{Effect of Pd loading amount}

The effect of $\mathrm{Pd}$ loading amount on $\mathrm{BrO}_{3}{ }^{-}$reduction and corresponding pseudo first-order rate constant $\left(\mathrm{k}, \mathrm{min}^{-1}\right)$ are

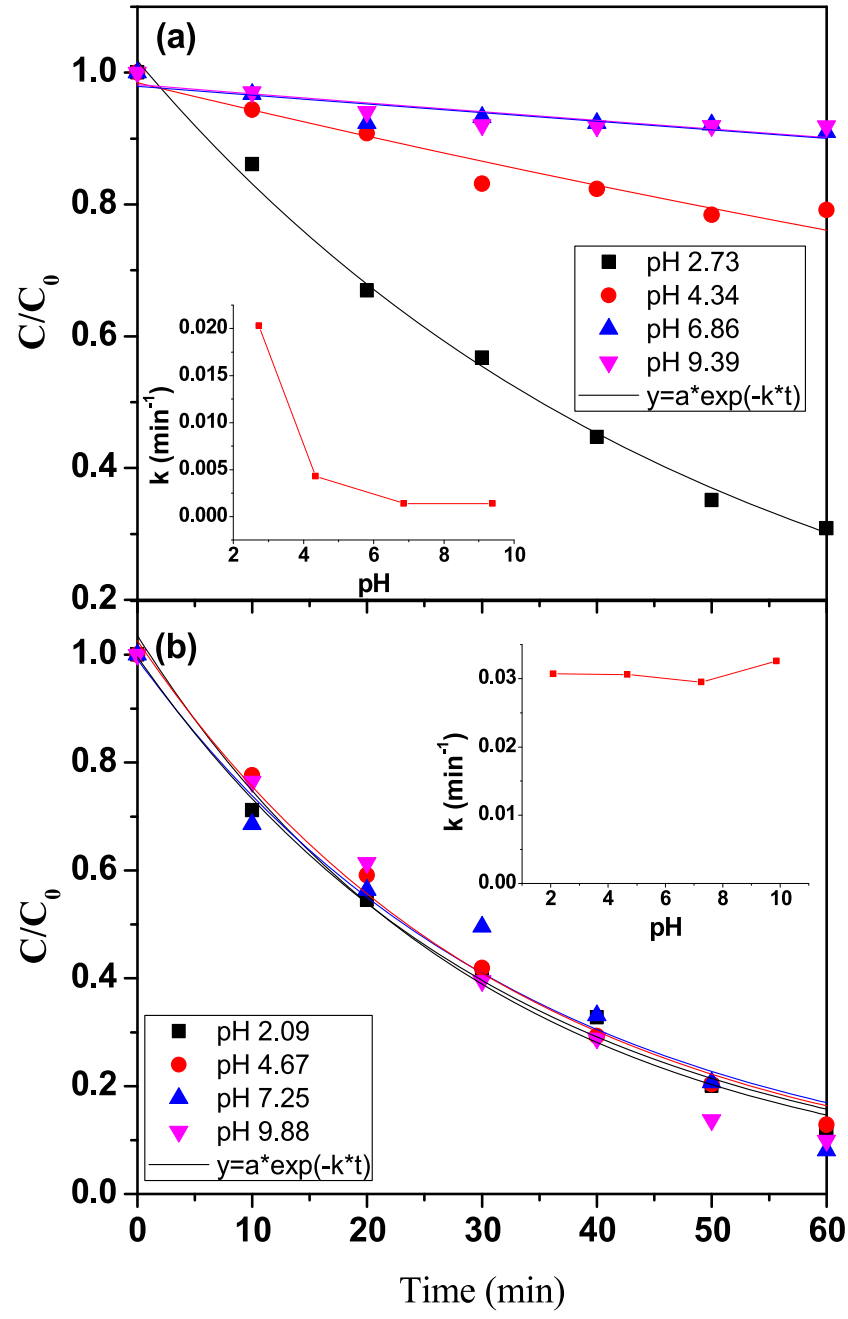

Fig. 3. Effect of solution $\mathrm{pH}$ on $\mathrm{BrO}_{3}{ }^{-}$reduction at the $\mathrm{Pd} / \mathrm{C}$ electrode at applied potential of (a) $-0.5 \mathrm{~V}$ and (b) $-2.0 \mathrm{~V}\left(5 \mathrm{mM} \mathrm{Na}_{2} \mathrm{SO}_{4} ; 0.66 \mu \mathrm{M}\right.$ initial $\mathrm{BrO}_{3}{ }^{-}$concentration; Pd loading amount: $0.73 \mathrm{mg} / \mathrm{cm}^{2}$ ). Inset is the effect of solution $\mathrm{pH}$ on the $\mathrm{BrO}_{3}{ }^{-}$reduction kinetics.

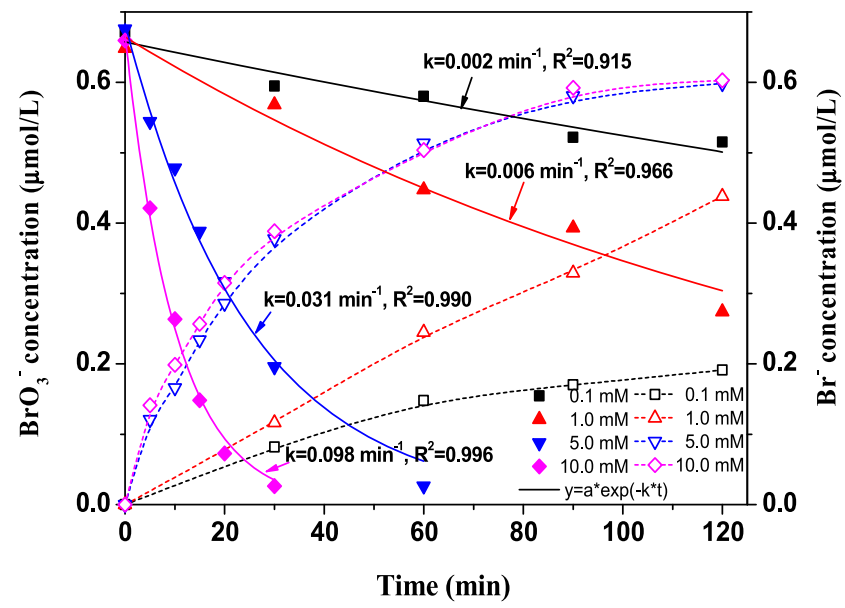

Fig. 4. Effect of supporting $\mathrm{Na}_{2} \mathrm{SO}_{4}$ electrolyte concentration on $\mathrm{BrO}_{3}{ }^{-}$reduction at the $\mathrm{Pd} / \mathrm{C}$ electrode during the potentiostatic electrolysis. Filled symbols denote $\mathrm{BrO}_{3}{ }^{-}$concentration and open symbols denote $\mathrm{Br}^{-}$concentration $(0.66 \mu \mathrm{M}$ initial $\mathrm{BrO}_{3}{ }^{-}$concentration; applied potential: $-2.0 \mathrm{~V}$; $\mathrm{pH} 7.25$; Pd loading amount: $0.73 \mathrm{mg} / \mathrm{cm}^{2}$ ). 


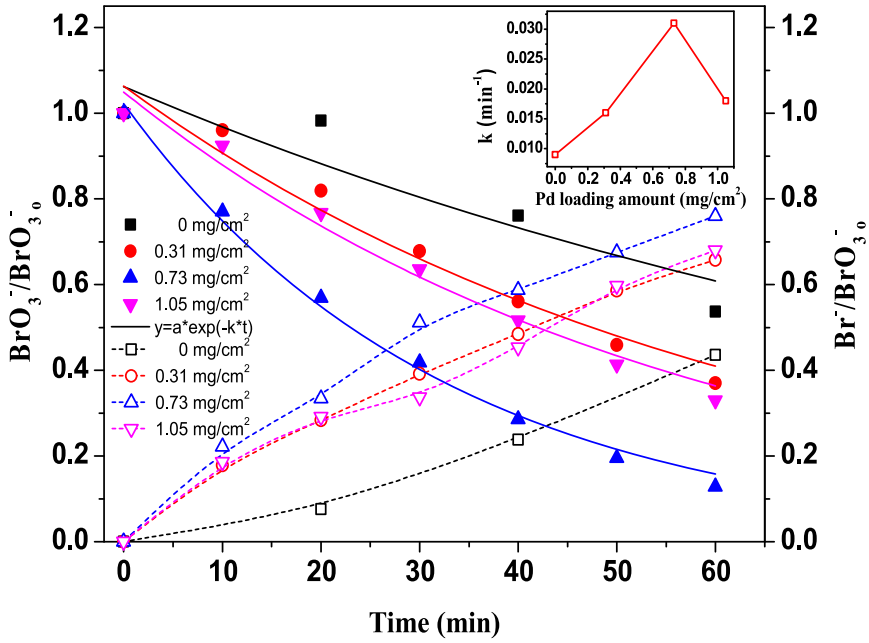

Fig. 5. Effect of Pd loading amount on $\mathrm{BrO}_{3}{ }^{-}$reduction and kinetics (inset) during potentiostatic electrolysis. Filled symbols denote normalized $\mathrm{BrO}_{3}{ }^{-}$concentration, open symbols denote normalized $\mathrm{Br}^{-}$concentration, and the lines denote the nonlinear curve fit of the data points in the same color $\left(5 \mathrm{mM} \mathrm{Na}_{2} \mathrm{SO}_{4} ; \mathrm{pH} 7.25 ; 0.66 \mu \mathrm{M}\right.$ initial $\mathrm{BrO}_{3}{ }^{-}$concentration; applied potential: $-2.5 \mathrm{~V}$ ).

investigated at the constant potential of $-2.5 \mathrm{~V}$. As shown in Fig. 5 , the rate constants $\mathrm{k}$ of $\mathrm{BrO}_{3}{ }^{-}$removal at the $0.73 \mathrm{mg} / \mathrm{cm}^{2} \mathrm{Pd} / \mathrm{C}$ electrode is nearly doubled in comparison to that at the 0.31 and $1.05 \mathrm{mg} / \mathrm{cm}^{2} \mathrm{Pd} / \mathrm{C}$ electrode, suggesting that the electrochemical activity of the $\mathrm{Pd} / \mathrm{C}$ electrode is not proportional to the Pd loading amount. It is obvious that the electroreduction removal of $\mathrm{BrO}_{3}{ }^{-}$is promoted at the $\mathrm{Pd} / \mathrm{C}$ electrode in comparison with that at the pure carbon fiber electrode, however, increase of the Pd loading amount does not continually improve the removal efficiency. As demonstrated by SEM images, the aggregation of large metallic $\operatorname{Pd}(0)$ particles becomes clear when the Pd loading amount is increased to be $1.05 \mathrm{mg} / \mathrm{cm}^{2}$, leading to the locally excessive $\mathrm{H}_{2}$ evolution, which may be responsible for the electrocatalytic performance of $\mathrm{BrO}_{3}{ }^{-}$reduction at the $1.05 \mathrm{mg} / \mathrm{cm}^{2} \mathrm{Pd} / \mathrm{C}$ electrode.

It is also worth mentioning that for unmodified carbon fiber electrode (Pd loading of $0 \mathrm{mg} / \mathrm{cm}^{2}$ ), the $\mathrm{BrO}_{3}{ }^{-}$content is found to remain nearly constant throughout the experiment at cathode potentials from $-0.15 \mathrm{~V}$ to $-2.0 \mathrm{~V}$ (Figure S4). And, a vigorous evolution of $\mathrm{H}_{2}$ has been observed at the carbon fiber electrode at $-2.0 \mathrm{~V}$. If the $\mathrm{BrO}_{3}{ }^{-}$removal mechanism involves indirect reduction, $\mathrm{BrO}_{3}{ }^{-}$ should be reduced by atomic $\mathrm{H}^{*}$ which can be generated in the step before $\mathrm{H}_{2}$ evolution [39]. This result indicates that the unmodified carbon fiber is not an efficient substrate for the reduction of $\mathrm{BrO}_{3}{ }^{-}$. It can also be deduced that the electrochemical reduction of $\mathrm{BrO}_{3}{ }^{-}$ at $-2.5 \mathrm{~V}$ occurs through direct reduction mechanism. Cheng et al. found that the direct electroreduction at the carbon electrode surface could not promote reductive dechlorination of 4-chlorophenol within $-1.1 \mathrm{~V}$ vs SCE because hydrogen gas escapes relatively easily from the surface [40]. By contrast, the Pd modified carbon cloth electrode exhibited the unique property to promote dechlorination of organic compounds due to the ability of Pd to absorb hydrogen into its lattice and to maintain a high surface concentration of hydrogen. In our case, the electroreduction of $\mathrm{BrO}_{3}{ }^{-}$at $-2.5 \mathrm{~V}$ on the carbon fiber electrode may be attributed to the more reducing cathode potentials employed in this study which can significantly enhance the direct electron transfer on its surface.

\subsection{Proposed mechanisms for electrocatalytic reduction of $\mathrm{BrO}_{3}$}

In order to investigate the electrochemical reduction of $\mathrm{BrO}_{3}{ }^{-}$at the Pd/C electrodes, linear sweep voltammograms (LSVs) with various $\mathrm{BrO}_{3}{ }^{-}$concentrations are recorded in the presence of $1.0 \mathrm{mM}$

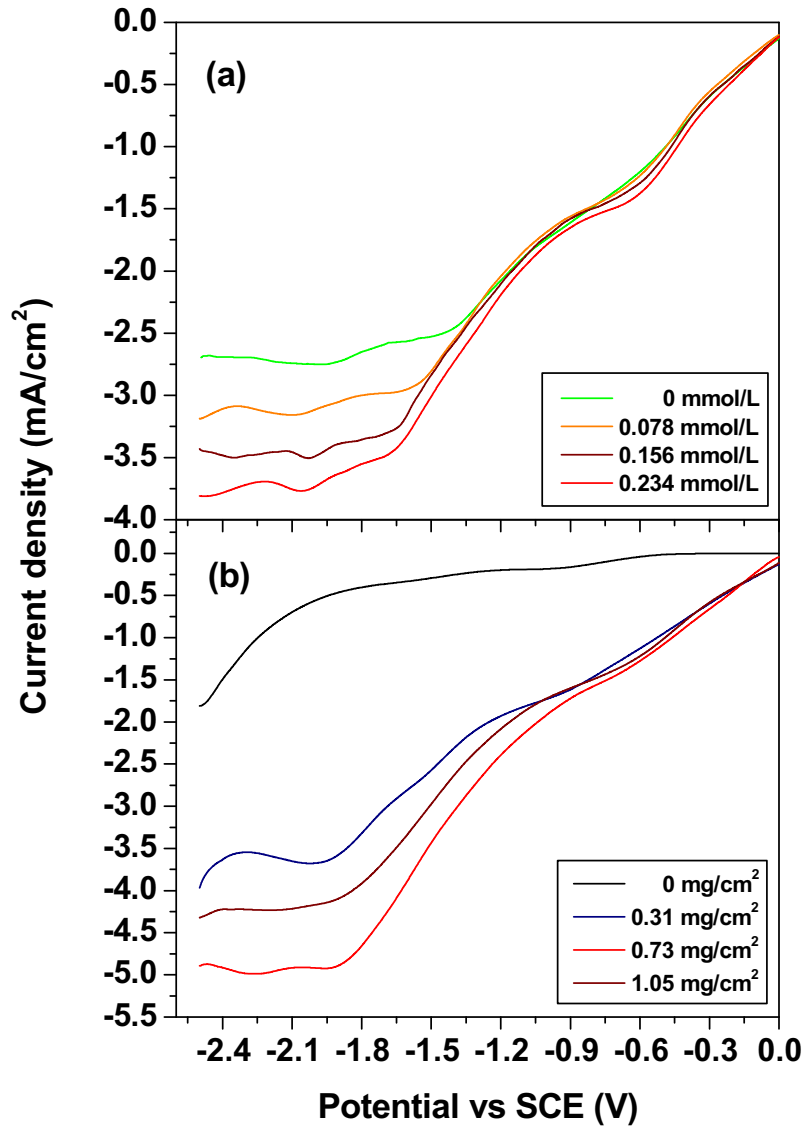

Fig. 6. Linear sweep voltammograms at $10 \mathrm{mV} / \mathrm{s}$ of (a) $0.73 \mathrm{mg} / \mathrm{cm}^{2} \mathrm{Pd} / \mathrm{C}$ electrode with gradient concentration of $\mathrm{BrO}_{3}{ }^{-}$in $1.0 \mathrm{mM} \mathrm{Na}_{2} \mathrm{SO}_{4}$ and (b) $\mathrm{Pd} / \mathrm{C}$ electrodes with different Pd loading amounts in $1.0 \mathrm{mM} \mathrm{Na}_{2} \mathrm{SO}_{4}$ and $0.5 \mathrm{mM} \mathrm{BrO}_{3}{ }^{-}$, $\mathrm{pH} 7.25$.

$\mathrm{Na}_{2} \mathrm{SO}_{4}$ at a scan rate of $10 \mathrm{mV} / \mathrm{s}$. A shoulder like reduction current maximum is observed at about $-2.0 \mathrm{~V}$, which is consistent with the results reported before as the maximum reduction rate is obtained at the same cathode potential (Fig. 6 (a)). It is clear that peak current increases with the increment of $\mathrm{BrO}_{3}{ }^{-}$concentration, indicating that more electrons take part in the reduction process. In comparison with the unmodified carbon fiber electrode, the current intensities of the $\mathrm{Pd} / \mathrm{C}$ electrodes with three Pd loadings are significantly increased (Fig. 6 (b)). Combined with the kinetics analysis in Fig. 5, it is concluded that Pd particles on the carbon fiber facilitate the electron transfer reaction and improve the cathode performance in $\mathrm{BrO}_{3}{ }^{-}$reduction. Among the three $\mathrm{Pd} / \mathrm{C}$ electrodes with different Pd loadings, the current densities are first increased and then decreased with the Pd loading amount. It is possible that the negative effect on $\mathrm{BrO}_{3}{ }^{-}$removal at high Pd loading amount is due to the presence of aggregation of large metallic $\operatorname{Pd}(0)$ particles. This unexpected appearance can result in locally excessive $\mathrm{H}_{2}$ evolution and thus hamper $\mathrm{BrO}_{3}{ }^{-}$migration and its reaction with atomic $\mathrm{H}^{*}$ on the catalytic active sites. By contrast, Chen et al. reported that increase of the Pd loading amount led to the increase in the initial $\mathrm{BrO}_{3}{ }^{-}$reduction rate without the negative influence [38]. It is important to note the difference in terms of catalytic system between the two studies. Chen et al. carried out the reduction experiments in a heterogeneous catalytic system using $\mathrm{Pd} / \mathrm{Al}_{2} \mathrm{O}_{3}$ and exogenous $\mathrm{H}_{2}$ as catalysts. However, the Pd/C electrode used in this study serves two purposes: it is the conducting matrix on which protons are reduced electrochemically to atomic or molecular hydrogen as well as available hydrogen is converted to atomic $\mathrm{H}^{*}$, and it also furnishes catalytic sites for the chemical reaction of atomic $\mathrm{H}^{*}$ with $\mathrm{BrO}_{3}{ }^{-}$. At lower catalyst loadings, the 


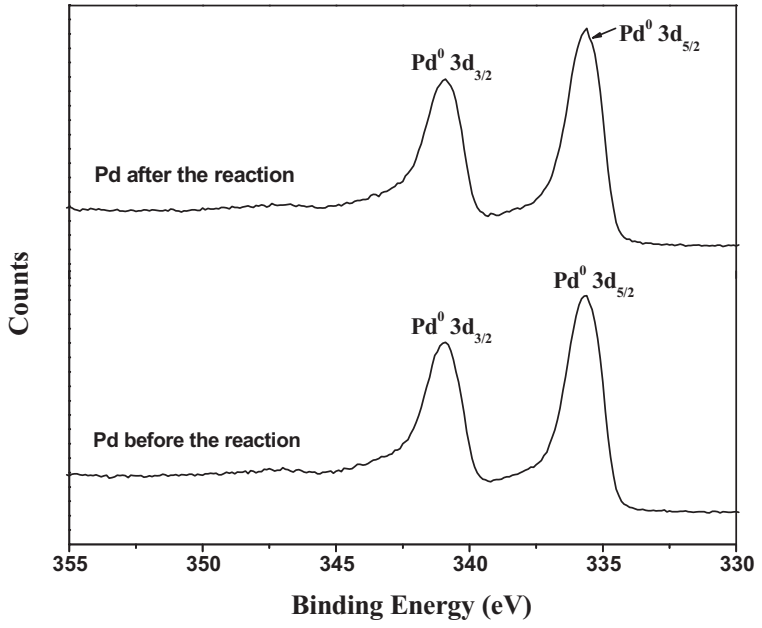

Fig. 7. XPS spectra of Pd on the Pd/C electrode before and after the electrochemical reduction $\left(5 \mathrm{mM} \mathrm{Na}_{2} \mathrm{SO}_{4} ; \mathrm{pH} 7.25 ; 0.66 \mu \mathrm{M}\right.$ initial $\mathrm{BrO}_{3}{ }^{-}$concentration; applied potential: $-2.0 \mathrm{~V}$; Pd loading amount: $0.73 \mathrm{mg} / \mathrm{cm}^{2}$ ).

electrochemical process fails to produce enough atomic $\mathrm{H}^{*}$ in the Pd lattice for $\mathrm{BrO}_{3}{ }^{-}$reduction. At high catalyst loadings, the cathode may restrict access of $\mathrm{BrO}_{3}-$ to the interior portions where $\mathrm{H}_{2}$ is excessively electrogenerated, which can be responsible for the decreased catalytic activity of the Pd/C electrode.

In the dechlorination reaction catalyzed by Pd in the electroreduction process, it is recognized that transitional C-Pd-Cl bond were formed, resulting in the presence of $\mathrm{Pd}(\mathrm{II})$ species. The chloroacetic acids were then attacked with atomic $\mathrm{H}^{*}$, followed by the $\mathrm{C}$ - $\mathrm{Cl}$ scission [30]. Herein, XPS is used to investigate the valence state of $\mathrm{Pd}$ coated on the $\mathrm{Pd} / \mathrm{C}$ electrode in the electroreduction of $\mathrm{BrO}_{3}{ }^{-}$ ions. A typical XPS survey spectrum is presented in Fig. 7. The Pd $3 \mathrm{~d}$ spectra before and after the electrochemical reduction exhibit spin-orbit doublet i.e. $3 \mathrm{~d}_{5 / 2}$ at $335.7 \mathrm{eV}$ and $3 \mathrm{~d}_{3 / 2}$ at $340.9 \mathrm{eV}$ respectively, which are attributed to the presence of metallic palladium $\operatorname{Pd}(0)$. According to the hydrodeoxygenation mechanism proposed by Chaplin et al., the reaction pathway of Pd-based catalytic reduction of $\mathrm{BrO}_{3}{ }^{-}$was characterized by the removal of oxygen atoms from oxyanions $\left(\mathrm{BrO}_{3}{ }^{-}\right)$by hydrogenation to water [29]. In this oxygen atom transfer mechanism, the roles of Pd for monometallic catalysts are to (1) dissociate $\mathrm{H}_{2}$ (ignoring the electroreduction of $\mathrm{H}^{+}$or $\mathrm{H}_{2} \mathrm{O}$ on polarized Pd particles due to that the electrons are provided by cathode) and (2) facilitate $\mathrm{H}_{2} \mathrm{O}$ formation from abstracted oxygen atoms. So it is concluded that neither palladiumbonding between the Pd atoms and the targeted oxyanions nor any oxidation species that can interact with $\operatorname{Pd}(0)$.

It is noteworthy that only $64 \%$ of the total $\mathrm{Br}^{-}$is detected within 30 min with the $10 \mathrm{mM} \mathrm{Na}_{2} \mathrm{SO}_{4}$, although $\mathrm{BrO}_{3}{ }^{-}$is almost completely removed in the same time scale. The molar concentration of $\mathrm{Br}^{-}$increases successively during the subsequent electrolysis, which is nearly identical to the initial $\mathrm{BrO}_{3}{ }^{-}$concentration within $90 \mathrm{~min}$. This observation indicates that some kinds of intermediates are generated under these conditions; otherwise, the increment of $\mathrm{Br}^{-}$should be identical to the decrement of $\mathrm{BrO}_{3}{ }^{-}$ during the electrocatalytic reduction process according to the stoichiometric relationship. Data in Fig. 8 shows that nearly $0.15 \mathrm{mg} / \mathrm{L}$ $\mathrm{HOBr} / \mathrm{OBr}^{-}$is generated during the $\mathrm{BrO}_{3}{ }^{-}$reduction at the carbon fiber electrode with initial $400 \mathrm{mg} / \mathrm{L} \mathrm{BrO}_{3}{ }^{-}$, and around $0.20 \mathrm{mg} / \mathrm{L}$ $\mathrm{HOBr} / \mathrm{OBr}^{-}$is detected at the $0.73 \mathrm{mg} / \mathrm{cm}^{2} \mathrm{Pd} / \mathrm{C}$ electrode under the same conditions. As reported by $\mathrm{Qu}$ et al., although the intermediates of $\mathrm{BrO}_{3}{ }^{-}$reduction involved $\mathrm{BrO}_{2}, \mathrm{HBrO}_{2}$ and $\mathrm{HBrO}$ which would undergo electrochemical reduction to produce $\mathrm{Br}_{2}$ rapidly, $\mathrm{Br}_{2}$ must then be reduced to $\mathrm{Br}^{-}$at the potential of the catalytic reduction, thus the final product of $\mathrm{BrO}_{3}{ }^{-}$reduction was $\mathrm{Br}^{-}[41]$.

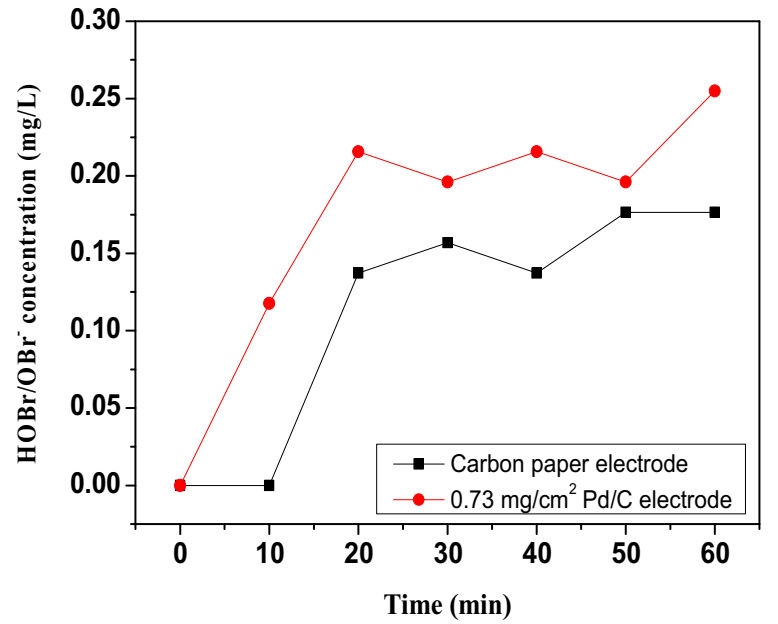

Fig. 8. $\mathrm{HOBr} / \mathrm{OBr}^{-}$generation at the carbon fiber electrode and the $0.73 \mathrm{mg} / \mathrm{cm}^{2} \mathrm{Pd} / \mathrm{C}$ electrode during the potentiostatic electrolysis $\left(10 \mathrm{mM} \mathrm{Na}_{2} \mathrm{SO}_{4} ; 400 \mathrm{mg} / \mathrm{L}\right.$ initial $\mathrm{BrO}_{3}{ }^{-}$concentration; applied potential: $-2.5 \mathrm{~V}$; $\mathrm{pH} 7.25$ ).

Therefore, the electrochemical reduction of $\mathrm{BrO}_{3}-$ produces intermediates $\left(\mathrm{BrO}_{2}, \mathrm{HBrO}_{2}, \mathrm{HBrO}, \mathrm{Br}_{2}\right)$, and these intermediates may have accumulated in the solution because of the fast reduction of $\mathrm{BrO}_{3}-$ at high $\mathrm{Na}_{2} \mathrm{SO}_{4}$ concentrations, which are subsequently reduced to $\mathrm{Br}^{-}$with the time evolution.

In our case, in the bias potential range from -0.3 to $-1 \mathrm{~V}$, the generation of atomic $\mathrm{H}^{*}$ is so weak that the direct reduction of $\mathrm{BrO}_{3}{ }^{-}$ by electrons provided at the cathode becomes the main process which was responsible for the $\mathrm{BrO}_{3}{ }^{-}$removal, i.e. the direct electron transfer on the cathode surface might be predominant, which is consistent with our observation that evolution of $\mathrm{H}_{2}$ (the electrogenerated $\mathrm{H}_{2}$ may be the main source for atomic $\mathrm{H}^{*}$ ) can only be found at potentials more negative than $-1.0 \mathrm{~V}$. The direct pathway can be expressed by Eq. (2):

$\mathrm{BrO}_{3}^{-}+6 \mathrm{H}^{+}+6 \mathrm{e}^{-} \leftrightarrow \mathrm{Br}^{-}+3 \mathrm{H}_{2} \mathrm{O}$

Therefore, the electrochemical reduction of $\mathrm{BrO}_{3}{ }^{-}$can be enhanced at low $\mathrm{pH}$ through the transition of the chemical equilibrium of the reduction reaction.

While in the range from -1.0 to $-2.0 \mathrm{~V}$, the sharp increase of the $\mathrm{BrO}_{3}{ }^{-}$removal efficiency from $24.0 \%$ to $87.2 \%$ is likely due to the fact that $\mathrm{BrO}_{3}$ - electroreduction mainly proceeded via the indirect reduction process, as in this process, the notably enlarged atomic $\mathrm{H}^{*}$ generated at the potential more negative than $-1.0 \mathrm{~V}$ on the $\mathrm{Pd} / \mathrm{C}$ surface can efficiently reduce $\mathrm{BrO}_{3}{ }^{-}$to $\mathrm{Br}^{-}$. When atomic $\mathrm{H}^{*}$ can be effectively generated on the cathode surface, corresponding Eq. (2) turns to be as follows:

$\mathrm{BrO}_{3}^{-}+6 \mathrm{H} * \leftrightarrow \mathrm{Br}^{-}+3 \mathrm{H}_{2} \mathrm{O}$

Then the reduction of $\mathrm{BrO}_{3}{ }^{-}$on the $\mathrm{Pd} / \mathrm{C}$ electrode proceeds with the indirect mechanism, as Pd serves to concentrate the available hydrogen which can be converted to atomic $\mathrm{H}^{*}$, thereby reducing the influence of $\mathrm{pH}$ on the $\mathrm{BrO}_{3}{ }^{-}$reduction. When the potential is set more negative than $-2.0 \mathrm{~V}$, the $\mathrm{Pd} / \mathrm{C}$ electrode achieves a stable electrocatalytic activity, indicating that the exterior of $\mathrm{Pd}$ lattice had been saturated with atomic $\mathrm{H}^{*}$. Accordingly, the electrochemical reduction of $\mathrm{BrO}_{3}{ }^{-}$proceeds with divergent mechanisms at different cathode potentials, thereby resulting in the different dependence of $\mathrm{BrO}_{3}{ }^{-}$removal on the $\mathrm{pH}$.

\section{Conclusions}

The electrochemical reduction of $\mathrm{BrO}_{3}{ }^{-}$at the $\mathrm{Pd} / \mathrm{C}$ electrode has been exhibited with the generation of $\mathrm{Br}^{-}$. The polycrystalline 
Pd particles dispersed evenly on the carbon fiber with ca. $40 \mathrm{~nm}$ in diameter. The removal of $\mathrm{BrO}_{3}{ }^{-}$followed the pseudo-first order kinetics. The rate constant $\mathrm{k}$ remained low when the applied potential was higher than $-1.0 \mathrm{~V}$ and was largely increased at low $\mathrm{pH}$ value. In the range from -1.0 to $-2.0 \mathrm{~V}$, the electroreduction rate was greatly increased and was hardly affected by solution $\mathrm{pH}$ at a relatively low potential. Accordingly, the electrochemical reduction of $\mathrm{BrO}_{3}{ }^{-}$was supposed to proceed with direct mechanism at potentials more positive than $-1.0 \mathrm{~V}$, and with indirect mechanism via reaction with atomic $\mathrm{H}^{*}$ at potentials more negative than $-1.0 \mathrm{~V}$. The strong $\mathrm{pH}$ dependence at $-0.5 \mathrm{~V}$ can be attributed to the transition of chemical equilibrium of the $\mathrm{BrO}_{3}{ }^{-}$direct reduction reaction involving $\mathrm{H}+$, while the slight $\mathrm{pH}$ dependence at $-2.0 \mathrm{~V}$ was due to that the atomic $\mathrm{H}^{*}$ concentrated on Pd lattice can efficiently reduce $\mathrm{BrO}_{3}-$ by indirect mechanism. Although Pd catalyst can actively produce adsorbed nascent $\mathrm{H}^{*}$, the locally excessive $\mathrm{H} 2$ evolution at high Pd loadings would inhibit the $\mathrm{BrO}_{3}{ }^{-}$reduction. $\mathrm{HOBr}$ and $\mathrm{OBr}^{-}$ were observed both at the unmodified carbon fiber electrode and at the $\mathrm{Pd} / \mathrm{C}$ electrode during the electroreduction process, which would finally be reduced to $\mathrm{Br}^{-}$.

\section{Supporting Information Available}

Additional figures (schematic of the electrocatalytic reactor employed in this work, EDX patterns of the Pd/C electrodes with various Pd loading amounts, XRD patterns of the carbon fiber electrode and the $0.73 \mathrm{mg} / \mathrm{cm}^{2} \mathrm{Pd} / \mathrm{C}$ electrode, and $\mathrm{BrO}_{3}{ }^{-}$removal and $\mathrm{Br}^{-}$formation at the unmodified carbon fiber electrode at different applied potentials) are included in the Supporting Information.

\section{Acknowledgments}

This work was supported by National Natural Science Foundation of China (No. 51221892, 51222802) and State Key Development Program of Basic Research of China (No. 2010CB933604).

\section{References}

[1] W.R. Haag, J. Hoigne, Ozonation of bromide-containing waters: kinetics of formation of hypobromous acid and bromate, Environ. Sci. Technol. 17 (1983) 261.

[2] H.S. Weinberg, C.A. Delcomyn, V. Unnam, Bromate in chlorinated drinking waters: Occurrence and implications for future regulation, Environ. Sci. Technol. 37 (2003) 3104

[3] World Health Organization, Bromate in Drinking-Water, Background Document for Preparation of WHO Guidelines for Drinking-Water Quality, World Health Organization Press, Geneva, 2005.

[4] R. Butler, A. Godley, L. Lytton, E. Cartmell, Bromate environmental contamination: Review of impact and possible treatment, Crit. Rev. Env. Sci. Technol. 35 (2005) 193.

[5] X. Zhao, H.J. Liu, Y.L. Shen, J.H. Qu, Photocatalytic reduction of bromate at $\mathrm{C}_{60}$ modified $\mathrm{Bi}_{2} \mathrm{MoO}_{6}$ under visible light irradiation, Appl. Catal. B: Environ. 106 (2011) 63.

[6] K. Listiarini, J.T. Tor, D.D. Sun, J.O. Leckie, Hybrid coagulation-nanofiltration membrane for removal of bromate and humic acid in water, J. Membr. Sci. 365 (2010) 154.

[7] M.J. Kirisits, V.L. Snoeyink, H. Inan, J.C. Chee-Sanford, L. Raskin, J.C. Brown, Water quality factors affecting bromate reduction in biologically active carbon filters, Water Res. 35 (2001) 891

[8] T.Y. Li, Y.M. Chen, P.Y. Wan, M.H. Fan, X.J. Yang, Chemical degradation of drinking water disinfection byproducts by millimeter-sized particles of iron-silicon and magnesium-aluminum alloys, J. Am. Chem. Soc. 132 (2010) 2500.

[9] L. Xie, C. Shang, Role of humic acid and quinine model compounds in bromate reduction by zerovalent iron, Environ. Sci. Technol. 39 (2005) 1092.

[10] J. Liu, J.W. Yu, D. Li, Y. Zhang, M. Yang, Reduction of bromate in a biological activated carbon filter under high bulk dissolved oxygen conditions and characterization of bromate-reducing isolates, Biochem. Eng. J. 65 (2012) 44

[11] L. Ding, Q. Li, H. Cui, R. Tang, H. Xu, X.C. Xie, J.P. Zhai, Electrocatalytic reduction of bromate ion using a polyaniline-modified electrode: An efficient and green technology for the removal of $\mathrm{BrO}_{3}{ }^{-}$in aqueous solutions, Electrochim. Acta 55 (2010) 8471.
[12] W.A.M. Hijnen, R. Jong, D. van der Kooij, Bromate removal in a denitrifying bioreactor used in water treatment, Water Res. 33 (1999) 1049.

[13] Q.L. Wang, S. Snyder, J. Kim, H. Choi, Aqueous ethanol modified nanoscale zerovalent iron in bromate reduction: synthesis, characterization, and reactivity, Environ. Sci. Technol. 43 (2009) 3292

[14] D.E. Kimbrough, I.H. Suffet, Electrochemical removal of bromide and reduction of THM formation potential in drinking water, Water Res. 36 (2002) 4902.

[15] N. Sonoyama, S. Seike, T. Sueoka, T. Sakata, Electrochemical decomposition of ppb level trihalomethane in tap water, J. Appl. Electrochem. 33 (2003) 1049.

[16] G.V. Korshin, M.D. Jensen, Electrochemical reduction of haloacetic acids and exploration of their removal by electrochemical treatment, Electrochim. Acta 47 (2001) 747

[17] J. Ghilane, M. Delamar, M. Guilloux-Viry, C. Lagrost, C. Mangeney, P. Hapiot, Indirect reduction of aryldiazonium salts onto cathodically activated platinum surfaces: Formation of metal-organic structures, Langmuir 21 (2005) 6422.

[18] L. Xiao, H. Dodi, A.G. Andrew, Electroreduction activity of hydrogen peroxide on Pt and Au electrodes, Langmuir 21 (2005) 9251.

[19] J. Radjenovic, M.J. Farre, Y. Mu, W. Gernjak, J. Keller, Reductive electrochemical remediation of emerging and regulated disinfection byproducts, Water Res. 46 (2012) 1705.

[20] N. Kishimoto, N. Matsuda, Bromate ion removal by electrochemical reduction using an activated carbon felt electrode, Environ. Sci. Technol. 43 (2009) 2054.

[21] X. Zhao, H.J. Liu, A.Z. Li, Y.L. Shen, J.H. Qu, Bromate removal by electrochemical reduction at boron-doped diamond electrode, Electrochim. Acta 62 (2012) 181.

[22] T. Li, J. Farrell, Reductive dechlorination of trichloroethene and carbon tetrachloride using iron and palladized-iron cathodes, Environ. Sci. Technol. 34 (2000) 173 .

[23] J.H. Brewster, Mechanisms of reductions at metal surfaces. I. A general working hypothesis, J. Am. Chem. Soc. 76 (1954) 6361.

[24] S.H. Yuan, X.H. Mao, A.N. Alshawabkeh, Efficient degradation of TCE in groundwater using $\mathrm{Pd}$ and electro-generated $\mathrm{H}_{2}$ and $\mathrm{O}_{2}$ : a shift in pathway from hydrodechlorination to oxidation in the presence of ferrous ions, Environ. Sci. Technol. 46 (2012) 3398.

[25] S.H. Yuan, M. Tian, X.H. Lu, Electrokinetic movement of hexachlorobenzene in clayed soils enhanced by Tween 80 and $\beta$-cyclodextrin, J. Hazard. Mater. 137 (2006) 1218.

[26] B. Yang, G. Yu, J. Huang, Electrocatalytic hydrodechlorination of 2, 4, 5 trichlorobiphenyl on a palladium-modified nickel foam cathode, Environ. Sci. Technol. 41 (2007) 7503.

[27] W. Pan, X.K. Zhang, H.Y. Ma, J.T. Zhang, Electrochemical synthesis, voltammetric behavior, and electrocatalytic activity of Pd nanoparticles, J Phys. Chem. C. 112 (2008) 2456

[28] P.M.L. Bonin, P. Edwards, D. Bejan, C.C. Lo, N.J. Bunce, A.D. Konstantinov, Catalytic and electrocatalytic hydrogenolysis of brominated diphenyl ethers, Chemosphere 58 (2005) 961

[29] B.P. Chaplin, M. Reinhard, W.F. Schneider, C. Schüth, J.R. Shapley, T.J. Strathmann, C.J. Werth, Critical review of Pd-based catalytic treatment of priority contaminants in water, Environ. Sci. Technol. 46 (2012) 11469.

[30] A.Z. Li, X. Zhao, Y.N. Hou, H.J. Liu, L.Y. Wu, J.H. Qu, The electrocatalytic dechlorination of chloroacetic acids at electrodeposited Pd/Fe-modified carbon paper electrode, Appl. Catal. B: Environ. 111 (112)(2012) 628

[31] K.D. Beard, M.T. Schaal, J.W. Van Zee, J.R. Monnier, Preparation of highly dispersed PEM fuel cell catalysts using electroless deposition methods, Appl. Catal. B: Environ. 72 (2007) 262.

[32] R. Rego, C. Oliveira, A. Velazquez, P.L. Cabot, A new route to prepare carbon paper-supported Pd catalyst for oxygen reduction reaction, Electrochem. Commun. 12 (2010) 745 .

[33] Y. Wang, J.H. Qu, Electrocatalytic reduction of nitrate in water with a palladiummodified copper electrode, Water Environ. Res. 78 (2006) 724

[34] C. Amorim, G. Yuan, P.M. Patterson, M.A. Keane, Catalytic hydrodechlorination over Pd supported on amorphous and structured carbon, J. Catal. 234 (2005) 268.

[35] M.A. Ryashentseva, Dehydrogenating properties of supported low-percentage palladium-containing catalysts, Russ. Chem. Rev. 64 (1995) 967.

[36] Y.P. Li, H.B. Cao, Y. Zhang, Reductive dehalogenation of haloacetic acids by hemoglobin-loaded carbon nanotube electrode, Water Res. 41 (2007) 197.

[37] X.Y. Wang, P. Ning, H.L. Liu, J. Ma, Dechlorination of chloroacetic acids by Pd/Fe nanoparticles: effect of drying method on metallic activity and the parameter optimization, Appl. Catal. B: Environ. 94 (2010) 55.

[38] H. Chen, Z.Y. Xu, H.Q. Wan, J.Z. Zheng, D.Q. Yin, S.R. Zheng, Aqueous bromate reduction by catalytic hydrogenation over $\mathrm{Pd} / \mathrm{Al}_{2} \mathrm{O}_{3}$ catalysts, Appl. Catal. B: Environ. 96 (2010) 307.

[39] M.R. Gennero de Chialvo, A.C. Chialvo, Kinetics of hydrogen evolution reaction with Frumkin adsorption: re-examination of the Volmer-Heyrovsky and Volmer-Tafel routes, Electrochim. Acta 44 (1998) 841.

[40] I.F. Cheng, Q. Fernando, N. Korte, Electrochemical dechlorination of 4chlorophenol to phenol, Environ. Sci. Technol. 31 (1997) 1074.

[41] J.Y. Qu, X.Q. Zou, B.F. Liu, S.J. Dong, Assembly of polyoxometalates on carbon nanotubes paste electrode and its catalytic behaviors, Anal. Chim. Acta 599 (2007) 51. 